\title{
Phase I clinical trial of multiple-peptide vaccination for patients with advanced biliary tract cancer
}

\author{
Atsushi Aruga ${ }^{1,2^{*}}$, Nobuhiro Takeshita ${ }^{1}$, Yoshihito Kotera', Ryuji Okuyama', Norimasa Matsushita', Takehiro Ohta ${ }^{1}$,
} Kazuyoshi Takeda ${ }^{3}$ and Masakazu Yamamoto ${ }^{1}$

\begin{abstract}
Background: The prognosis of patients with advanced biliary tract cancer (BTC) is extremely poor and only a few standard treatments are available for this condition. We performed a phase I trial to investigate the safety, immune response and anti-tumor effect of vaccination with three peptides derived from cancer-testis antigens.

Methods: This study was conducted as a phase I trial. Nine patients with advanced BTC who had unresectable tumors and were refractory to standard chemotherapy were enrolled. Three HLA-A*2402 restricted epitope peptides-cell division cycle associated 1 (CDCA1), cadherin 3 (CDH3) and kinesin family member 20A (KIF20A)-were administered subcutaneously, and the adverse events and immune response were assessed. The clinical effects observed were the tumor response, progression-free survival (PFS) and overall survival (OS).
\end{abstract}

Results: The three-peptide vaccination was well-tolerated up to a dose of $3 \mathrm{mg}$ per peptide (9 $\mathrm{mg}$ total). No grade 3 or 4 adverse events were observed after vaccination. Peptide-specific T cell immune responses were observed in all patients and stable disease was observed in 5 of 9 patients. The median PFS and OS were 3.4 and 9.7 months. The Grade 2 injection site reaction and continuous vaccination after PD judgment appeared to be prognostic of OS. Conclusions: Multiple-peptide vaccination was well tolerated and induced peptide-specific T-cell responses.

Trial registration: This study was registered with the University Hospital Medical Information Network Clinical Trials Registry (UMIN-CTR000003229).

Keywords: Cancer vaccine, Peptide vaccine, Immunotherapy, Biliary tract cancer

\section{Background}

Biliary tract cancer (BTC) is not a common disease worldwide, but is prevalent in East Asia and Latin America. The occurrence rate is gradually increasing and there is a high mortality rate because most cases of BTC are not diagnosed until advanced and inoperable. At this time, very few standard treatments have been established for BTC $[1,2]$, and thus development of new treatment modalities is urgently needed. Recently, cancer vaccines using synthetic peptides have been undergoing development throughout the world, and some of them have already been shown to be safe and effective [3-12]. We have previously reported that cancer peptide vaccines are capable of inducing

\footnotetext{
* Correspondence: aruga.atsushi@twmu.ac.jp

${ }^{1}$ Department of Gastroenterological Surgery, Tokyo Women's Medical

University, 8-1 Kawada-cho, Shinjuku-ku, Tokyo 162-8666, Japan

${ }^{2}$ Institute of Advanced Biomedical Engineering and Science, Tokyo Women's

Medical University, 8-1 Kawada-cho, Shinjuku-ku, Tokyo 162-8666, Japan

Full list of author information is available at the end of the article
}

antigen-specific cytotoxic $\mathrm{T}$ cells in vivo and providing some clinical benefit to some patients with advanced biliary tract cancer [13]. In this study, we selected three cancer-testis antigens that were identified by using cDNA microarray technology coupled with laser microdissection and were overexpressed in nearly $100 \%$ of BTC. We then performed a phase I study to assess the safety and antigenspecific immune response of a three-peptide vaccination using the selected antigens in patients with advanced biliary tract cancer. Patients were vaccinated on a continuous basis over the long-term even if their disease had progressed. We assessed the safety of the vaccination by CTCAE v3.0 as a primary endpoint and the antigen-specific immune response and clinical effects as secondary endpoints.

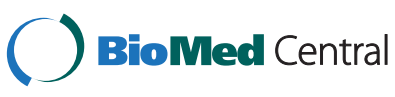

(c) 2014 Aruga et al.; licensee BioMed Central Ltd. This is an Open Access article distributed under the terms of the Creative Commons Attribution License (http://creativecommons.org/licenses/by/2.0), which permits unrestricted use, distribution, and reproduction in any medium, provided the original work is properly credited. The Creative Commons Public Domain Dedication waiver (http://creativecommons.org/publicdomain/zero/1.0/) applies to the data made available in this article unless otherwise stated. 


\section{Methods}

\section{Patient eligibility}

Patients with unresectable BTC (intrahepatic bile duct cancer, extrahepatic bile duct cancer and gallbladder cancer) who were refractory to standard chemotherapy were eligible for this study. All patients were required to have an HLA-A type of $A * 2402$. Additional inclusion criteria consisted of age between 20 and 80 years, no severe organ function impairment, white blood cell count between 2000 and $10000 / \mathrm{mm}^{3}$, hemoglobin $>8 \mathrm{mg} / \mathrm{dL}$, platelet count $>100,000 / \mathrm{mm}^{3}$, AST and ALT $<100 \mathrm{IU} / \mathrm{L}$, and total bilirubin $<2 \mathrm{mg} / \mathrm{dl}$. Performance status measured by the ECOG scale was 0 to 2 . It was required that there be an at least 4-week interval since the last chemotherapy. The exclusion criteria consisted of pregnancy, serious infections, severe underlying disease, severe allergic disease and a judgment of unsuitability by the principal investigator.

\section{Study design and endpoints}

This study was conducted as a phase I trial. Patients who received standard chemotherapy under a diagnosis of inoperable BTC between June 2009 and May 2010 were invited to participate after providing their informed consent. The HLA-A genotypes of these patients were examined, and the 9 patients with an HLA-A type of $A * 2402$ were enrolled. Three peptides were used for the vaccine, CDCA1 (VYGIRLEHF) [14], CDH3 (DYLNEW GSRF) [15] and KIF-20A (KVYLRVRPLL) [16]. These peptides were chosen from among the antigens identified by using cDNA microarray technology coupled with laser microdissection and were the most overexpressed in BTCs. The purity $(>97 \%)$ of the peptides was determined by analytical high-performance liquid chromatography (HPLC) and mass spectrometry analysis. The endotoxin levels and bioburden of these peptides were tested and determined to be within acceptable levels based on the GMP grade for the vaccines (PolyPeptide or NeoMPS Inc., San Diego, CA, USA). These peptides were mixed with incomplete Freund's adjuvant (IFA; Montanide ISA51, SEPPIC), which has been used in many clinical studies, and were injected subcutaneously into the inguinal or the axicilla site. Each of the three peptides at doses of $1 \mathrm{mg}, 2 \mathrm{mg}$ or $3 \mathrm{mg}$ was injected subcutaneously into three patients once a week until the 8th vaccination and every two weeks after the 9th vaccination as a monotherapy as long as possible even if the patient was judged to exhibit disease progression. The primary endpoint in this study was the assessment of toxicities caused by the vaccination based on the Common Terminology Criteria for Adverse Events version 3.0 (CTCAE v.3.0). The secondary endpoints were assessment of the immunological response, tumor response, progression-free survival (PFS) and overall survival (OS) from the $1^{\text {st }}$ dose given. For the image analysis, CT scan or ultrasound was performed during the pre-vaccination period and at every $4^{\text {th }}$ vaccination. This study was approved by the institutional review board at Tokyo Women's Medical University and was registered with the University Hospital Medical Information Network Clinical Trials Registry (UMIN-CTR number, 000003229). Informed consent was obtained from all the patients and the procedures followed were in accordance with the Declaration of Helsinki.

\section{Lymphocyte preparation for immunologic monitoring}

The performance of the immunologic assay at the center laboratory was periodically standardized and validated by Clinical Laboratory Improvements Amendments (CLIA) and the International Conference on Harmonization of Technical Requirements for Registration of Pharmaceuticals for Human use (ICH) guidelines. PBLs were obtained from the patients at the pre-vaccination period and after every $4^{\text {th }}$ vaccination. Peripheral blood was taken by venipuncture, collected in an EDTA tube and transferred to the center laboratory within 24 hrs at room temperature. Within 24 hrs of blood collection, PBLs were isolated with Ficoll-Paque Plus (GE Healthcare Bio-sciences, Piscataway, $\mathrm{NJ}$ ) density gradient solution and were stored at $-80^{\circ} \mathrm{C}$ in cell stock media (Juji Field) without serum at $5 \times 10^{6}$ cells/ $\mathrm{ml}$. After thawing, the cell viability was confirmed to be more than $90 \%$ by trypan-blue dye.

\section{Enzyme-linked immunospot (ELISPOT) assay}

The peptide-specific CTL response was estimated by ELI SPOT assay following in vitro sensitization. Frozen PBMCs derived from the same patient were thawed at the same time, and the viability was confirmed to be more than $90 \%$. PBMCs $\left(5 \times 10^{5} / \mathrm{ml}\right)$ were cultured with $10 \mu \mathrm{g} / \mathrm{ml}$ of the respective peptide and $100 \mathrm{IU} / \mathrm{mL}$ of IL-2 (Novartis, Emeryville, CA) at $37^{\circ} \mathrm{C}$ for two weeks. The peptide was added to the culture at day 0 and day 7 . Following CD4+ cell depletion by a Dynal CD4 Positive Isolation Kit (Invitrogen, Carlsbad, CA), an IFN- $\gamma$ ELISPOT assay was performed using a Human IFN- $\gamma$ ELISpot PLUS kit (MabTech, Nacka Strand, Sweden) according to the manufacturer's instructions. Briefly, HLA-A*2402-positive B-lymphoblast TISI cells (IHWG Cell and Gene Bank, Seattle, WA) were incubated with $20 \mu \mathrm{g} / \mathrm{ml}$ of vaccinated peptides overnight, and then the residual peptide in the media was washed out to prepare peptide-pulsed TISI cells as the stimulation cells. Prepared CD4- cells were cultured with peptide-pulsed TISI cells $\left(2 \times 10^{4}\right.$ cells/well $)$ at a $1 / 1$, $1 / 2,1 / 4$ or $1 / 8$ mixture ratio of responder cells to stimulator cells ( $\mathrm{R} / \mathrm{S}$ ratio) on a 96-well plate (Millipore, Bedford, $\mathrm{MA})$ at $37^{\circ} \mathrm{C}$ overnight. Non-peptide-pulsed TISI cells were used as a negative control for the stimulator cells. To confirm IFN- $\gamma$ productivity, the responder cells were stimulated with PMA and ionomycin $(3 \mu \mathrm{g} / \mathrm{ml})$ overnight, then applied to an IFN- $\gamma$ ELISPOT assay $\left(2.5 \times 10^{3}\right.$ cells/well $)$ 
Table 1 Patient characteristics

\begin{tabular}{lccccc}
\hline Patients & Age/Sex & \multicolumn{2}{c}{ Tumor site* } & Prior therapy** & $\begin{array}{c}\text { Peptide } \\
\text { (mg) }\end{array}$ \\
\cline { 2 - 4 } & & Primary & Metastases & Ope, GEM, CBDCA, TS-1, DTX \\
2 & 38/F & GB & Lung, bone & Liver, LN & Ope, GEM, TS-1 \\
3 & $69 / M$ & GB & Liver, LN & Ope, GEM, TS-1 & 1 \\
4 & $60 / F$ & IBD & Liver, lung, LN, bone & Ope, GEM, TS-1 & 2 \\
5 & $66 / F$ & IBD & Lung & Ope, GEM, TS-1 & 2 \\
6 & $75 / M$ & IBD & Liver, LN, peritoneum & GEM, TS-1, CDDP & Ope, GEM, TS-1 \\
7 & $61 / F$ & EBD & Liver, LN & Ope, GEM, TS-1 & 3 \\
8 & $46 / M$ & EBD & Lung & Ope, GEM, TS-1 & 3 \\
9
\end{tabular}

*IBD: intrahepatic bile duct; GB: gallbladder; EBD: extrahepatic bile duct; LN: lymph node.

**Ope: operation; GEM: gemcitabine; CBDCA: carboplatin; TS-1: tegafur-gimeracil-oteracil potassium; DTX: docetaxcel; CDDP: cisplatin.

without stimulator cells. All ELISPOT assays were performed in triplicate wells. The plates were analyzed by an automated ELISPOT reader, ImmunoSPOT S4 (Cellular Technology, Ltd., Shaker Heights, $\mathrm{OH}$ ) and ImmunoSpot Professional Software Version 5.0 (Cellular Technology, Ltd.). The number of peptide-specific spots was calculated by subtracting the number of spots in the control well from the number of spots in each of the wells with peptidepulsed TISI cells. The sensitivity of our ELISPOT assay was estimated as an approximately average level by an ELISPOT panel of the Cancer Immunotherapy Consortium [CIC (http://www.cancerresearch.org/cic/tools-initiatives/immuneassay-proficiency-harmonizationpanels)].

\section{Flow cytometry assay}

Conventional two-color analysis was performed with FITCconjugated anti-human CXCR3 mAb plus PE-conjugated anti-human CCR4 mAb (R\&D Systems, Minneapolis, MN) in order to assess the host immune condition of the type $1 /$ type 2 subsets.

\section{Statistical analysis}

PFS and OS rates were analyzed using the Kaplan-Meier method. Statistical analyses of prognostic factors were done using the log-rank test. A p-value less than 0.05 was considered to indicate a statistically significant difference. All statistical analyses were conducted using IBM SPSS Statistics 21 (IBM, USA).

\section{Results}

\section{Patient characteristics}

Nine patients (4 males and 5 females; median age: 61.4 years; range: 38-76) whose HLA type was $A * 2402$ were enrolled in this study (Table 1). Their primary tumor site was the intrahepatic bile duct in 4 cases, the extrahepatic bile duct in 3 cases, and the gallbladder in 2 cases. They had several metastases to the liver, lungs, lymph nodes, peritoneum and bone. Previous therapies consisted of operation, gemcitabine (GEM), cisplatin (CD $\mathrm{DP})$, tegafur-gimeracil-oteracil potassium (TS-1), carboplatin (CBDCA) or docetaxcel (DTX). One patient dropped out after the $1^{\text {st }}$ follow-up study because of another disease and 4 patients elected to stop vaccination at the time of PD judgment. Four patients decided to continue the vaccination as long as possible after PD judgment.

\section{Assessment of toxicity}

Toxicity was assessed by CTCAE v3.0 (Table 2). Four of 9 patients developed grade 1 injection site reaction and 5 developed grade 2 injection site reaction. Low hemoglobin, WBC, lymphopenia, neutrophil and platelet counts were observed before the $1^{\text {st }}$ vaccination and were not worsened throughout the vaccination term. No other adverse events were seen throughout the peptide vaccination. Therefore, the multiple-peptide vaccine therapy was well-tolerated up to a dose of $3 \mathrm{mg}$ for each peptide, or $9 \mathrm{mg}$ total.

Table 2 Summary of adverse events

\begin{tabular}{|c|c|c|c|c|c|}
\hline Adverse events & Total (\%) & Grade 1 (\%) & Grade 2 (\%) & Grade 3 (\%) & Grade 4 (\%) \\
\hline Hemoglobin & $5(55.6)$ & $3(33.3)$ & $2(22.2)$ & 0 & 0 \\
\hline WBC & $2(22.2)$ & 0 & $2(22.2)$ & 0 & 0 \\
\hline Lymphopenia & $3(33.3)$ & $2(22.2)$ & 0 & $1(11.1)$ & 0 \\
\hline Neutrophil & $2(22.2)$ & 0 & $2(22.2)$ & 0 & 0 \\
\hline Platelet & $3(33.3)$ & $3(33.3)$ & 0 & 0 & 0 \\
\hline Injection site reaction & $9(100)$ & $4(44.4)$ & $5(55.6)$ & 0 & 0 \\
\hline
\end{tabular}



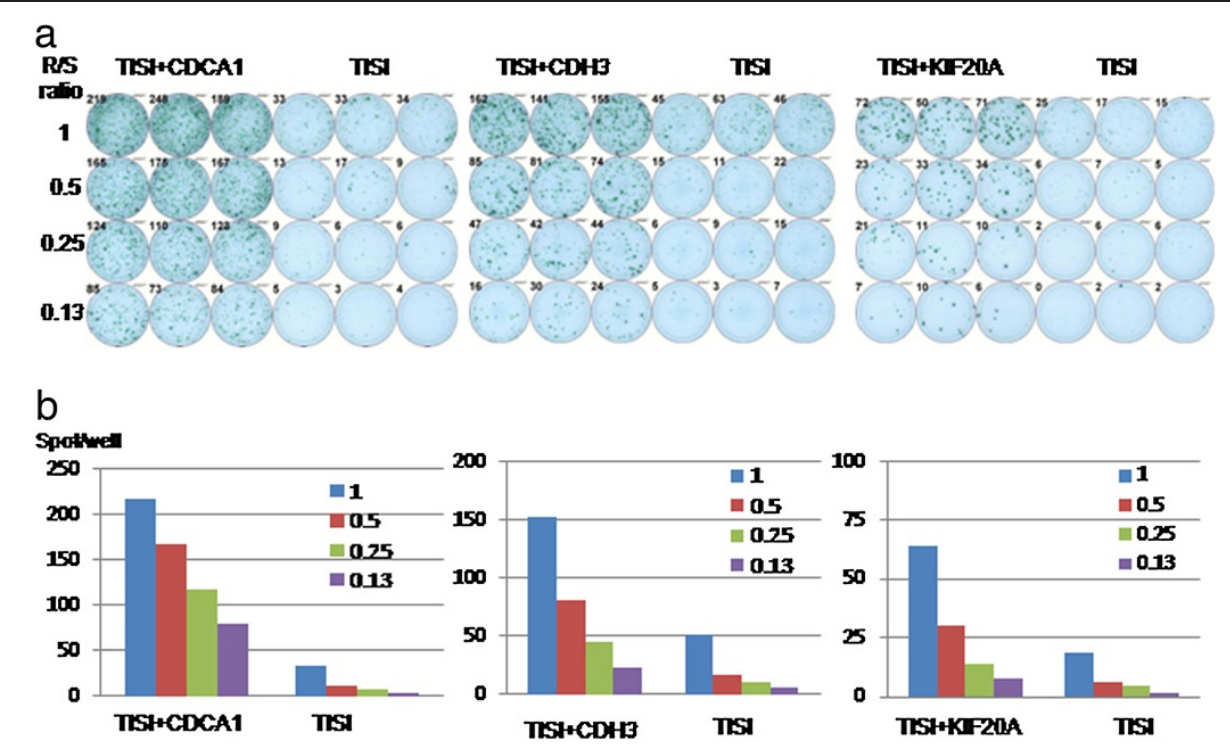

Figure 1 Immunological monitoring assay of T cell response to CDCA1, CDH3 and KIF20A in patient 8. (a) IFN- $-\gamma$ ELISPOT assay for CDCA1, CDH3 and KIF20A. (b) IFN- $\gamma$ positive spots at several R/S ratio.

\section{Antigen-specific immune response}

Antigen-specific immune response was assessed by the ELISPOT assay. In the assay, CDCA1, CDH3 and KIF20A peptides-specific IFN- $\gamma$ spots were observed in 9 of 9 patients (Figure 1). The response to every antigen in every patient was determined using our algorithm (Additional file 1: Figure S1) is summarized in Tables 3 and 4. The number of peptide-specific IFN- $\gamma$ spots gradually increased with the number of vaccinations (Figure 2). These immune responses were not found for all antigens or for all patients after 8 vaccinations when the clinical assessments were done, but they were observed after the judgment of PD in some patients with continuous peptide vaccination. The group receiving $3 \mathrm{mg}$ of each peptide tended to show stronger CTL induction throughout the course of this study.

\section{Clinical response}

As shown in Tables 3, 5 patients had stable disease (SD) and 4 had progressive disease (PD) as judged after the $8^{\text {th }}$ vaccination. The 8 patients continued to be administered the vaccination and 4 of them continued to receive the vaccination for as long as possible, even if their disease developed PD. The vaccinations eventually achieved disease stability in the patients who received the long-term vaccination (Figure 3 shows the CT scan of patient 4), but in the end their diseases progressed, and they had all died within 2 years of the $1^{\text {st }}$ vaccination. Their median progression-free survival (PFS) for all patients after the first vaccination was 3.4 months (95\% CI: 0-7.0) and the 1 year PFS was $11.1 \%$ (Figure $4 \mathrm{a}$ ). The median overall survival (OS) for all patients was 9.7 months (95\% CI: $1.4-18.0$ ) and the 1 year OS was $22.2 \%$ (Figure $4 \mathrm{~b}$ ).

Table 3 Summary of clinical outcome and immunological response

\begin{tabular}{lccccccccc}
\hline Patients & No. of vaccine & Clinical response* & PFS (days) & OS (days) & After vaccine & ISR $^{* *}$ (Grade) & \multicolumn{2}{c}{ Peptide-specific CTL } \\
\hline 1 & & & & & & & CDCA1 & CDH3 & KIF20A \\
2 & 16 & SD & 212 & 310 & No & 2 & 0 & $1+$ & $1+$ \\
3 & 8 & PD & 53 & 134 & No & 1 & $2+$ & 0 & $1+$ \\
4 & 18 & SD & 127 & 205 & No & 1 & $1+$ & $2+$ & $1+$ \\
5 & 19 & SD & 505 & 659 & Yes & 2 & $1+$ & 0 & $1+$ \\
6 & 27 & SD & 225 & 290 & No & 2 & $1+$ & $1+$ & $3+$ \\
7 & 10 & SD & 101 & 101 & & 1 & $1+$ & $1+$ & 0 \\
8 & 13 & PD & 64 & 164 & Yes & 1 & $2+$ & $1+$ & $2+$ \\
9 & 24 & PD & 64 & 353 & Yes & 2 & $3+$ & $3+$ & $3+$ \\
\hline
\end{tabular}

*SD: stable disease; PD: progressive disease.

**ISR: injection site reaction. 
Table 4 CTL response to CDCA1, CDH3 and KIF20A

\begin{tabular}{|c|c|c|c|c|c|c|}
\hline \multirow[t]{2}{*}{ Peptide dose } & \multirow[t]{2}{*}{ No. } & \multirow[t]{2}{*}{ Course } & \multicolumn{4}{|c|}{ CTL response } \\
\hline & & & CDCA1 & $\mathrm{CDH} 3$ & KIF20A & Positive control \\
\hline \multirow[t]{10}{*}{$1 \mathrm{mg}$} & 1 & Pre & - & + & - & +++ \\
\hline & & Post 1 & - & - & + & +++ \\
\hline & & Post 2 & - & - & - & +++ \\
\hline & 2 & Pre & - & - & - & +++ \\
\hline & & Post 1 & ++ & - & + & +++ \\
\hline & 3 & Pre & + & - & - & +++ \\
\hline & & Post 1 & $N A^{*}$ & NA & NA & +++ \\
\hline & & Post 2 & - & + & - & +++ \\
\hline & & Post 3 & + & ++ & - & +++ \\
\hline & & Post 4 & + & - & + & +++ \\
\hline \multirow[t]{14}{*}{$2 \mathrm{mg}$} & 4 & Pre & + & - & + & +++ \\
\hline & & Post 1 & - & - & + & +++ \\
\hline & & Post 2 & + & - & + & +++ \\
\hline & & Post 3 & - & - & - & +++ \\
\hline & 5 & Pre & - & - & - & +++ \\
\hline & & Post 1 & - & - & - & +++ \\
\hline & & Post 2 & - & - & + & +++ \\
\hline & & Post 3 & + & - & +++ & +++ \\
\hline & & Post 4 & - & - & ++ & +++ \\
\hline & & Post 5 & + & + & - & +++ \\
\hline & & Post 6 & - & - & - & +++ \\
\hline & 6 & Pre & - & + & - & +++ \\
\hline & & Post 1 & + & + & - & +++ \\
\hline & & Post 2 & + & + & - & +++ \\
\hline \multirow[t]{14}{*}{$3 \mathrm{mg}$} & 7 & Pre & NA & NA & NA & +++ \\
\hline & & Post 1 & - & - & - & +++ \\
\hline & & Post 2 & ++ & + & ++ & +++ \\
\hline & 8 & Pre & - & - & + & +++ \\
\hline & & Post 1 & - & + & - & +++ \\
\hline & & Post 2 & ++ & + & ++ & +++ \\
\hline & & Post 3 & +++ & +++ & + & +++ \\
\hline & & Post 5 & +++ & +++ & +++ & +++ \\
\hline & 9 & Pre & + & - & + & +++ \\
\hline & & Post 1 & ++ & + & + & +++ \\
\hline & & Post 2 & - & + & - & +++ \\
\hline & & Post 3 & - & +++ & + & +++ \\
\hline & & Post 4 & ++ & - & - & +++ \\
\hline & & Post 6 & ++ & + & ++ & +++ \\
\hline
\end{tabular}

*NA: not analyzed.

Univariate analysis of the prognostic factors

The results of the univariate analysis of the prognostic factors are described in Table 5. The patients who developed grade 2 local skin reaction at the vaccination site showed a median OS of 11.8 months (95\% CI: 8.7-14.9). This was better than the OS of patients with grade 1 local skin reaction of 4.5 months (95\% CI: 2.4-6.5). There was a significant difference between these 2 groups $(\mathrm{p}=0.003)$ 


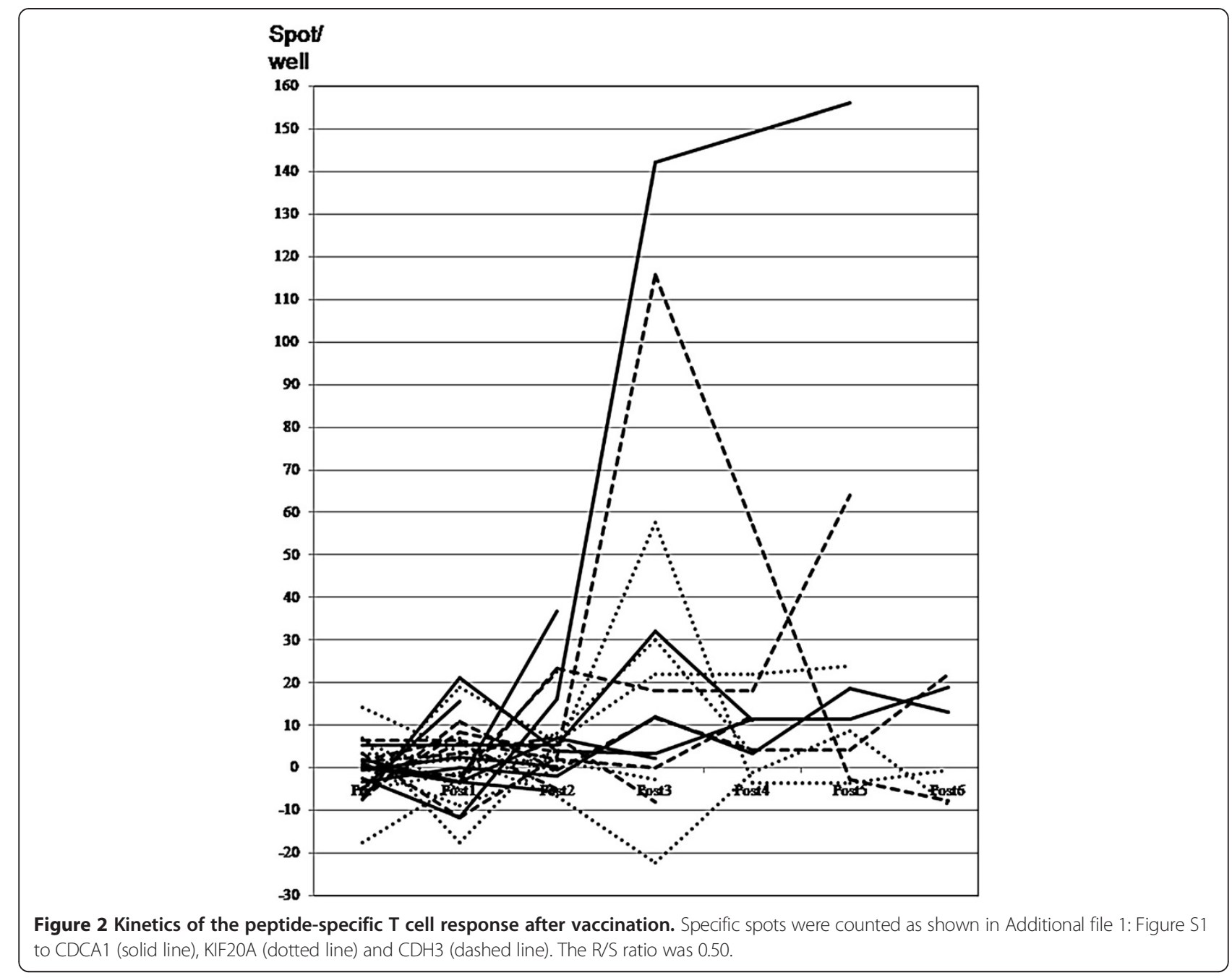

\section{Table 5 Prognostic factors of PFS or OS}

\begin{tabular}{lll}
\hline Factors & PFS & OS \\
\hline Sex (male/female) & 0.426 & 0.302 \\
Age $(\geqq 61 /<61)$ & 0.706 & 0.084 \\
CRP $(\geqq 1.5 /<1.5)$ & 0.654 & 0.832 \\
Hemoglobin $(\geqq 12 /<12)$ & 0.351 & 0.435 \\
Lymphocyte $(\%)(\geqq 27 /<27)$ & 0.145 & 0.132 \\
Lymphocyte (number) $(\geqq 1500 /<1500)$ & 0.488 & 0.900 \\
CDCA1 CTL spots $(\geqq 2+/<2+)$ & 0.004 & 0.870 \\
CHD3 CTL spots $(\geqq 2+/<2+)$ & 0.235 & 0.611 \\
KIF20A CTL spots $(\geqq 2+/<2+)$ & 0.486 & 0.840 \\
CXCR3 + CCR4- T cells ( $\geqq 8 \% /<8 \%)$ & 0.046 & 0.966 \\
CXCR3 + CCR4- $T$ cells (up/down) & 0.007 & 0.604 \\
Injection site reaction $(\geqq$ Grade2/<Grade2) & 0.145 & 0.003 \\
Continuous vaccination after PD (Yes/No) & - & 0.007 \\
\hline
\end{tabular}

(Figure 4c). The OS of the patients with continuous vaccinations was also better than that of the patients who stopped the vaccination as their disease progressed. The OS of the patients with continuous vaccinations was 5.1 months (95\% CI: 0-11.3) and that of the patients who stopped the vaccination was 2.6 months (95\% CI: 2.1-3.1). There was a statistically significant difference between these 2 groups $(\mathrm{p}=0.007)$ (Figure $4 \mathrm{~d})$.

\section{Analysis of the relation between better PFS and the type} 1 host immune condition

The type 1 host immune condition was analyzed based on the ratio of the CXCR3 + CCR4- T cell population (mean: $8.1 \%$ ). The patients with a CXCR3 + CCR4- T cell population of more than $8 \%$ showed longer PFS and the patients whose CXCR3 + CCR4- $\mathrm{T}$ cell population increased after the $4^{\text {th }}$ vaccinations also showed longer PFS (Table 5). Most of the patients with stable disease (SD) showed an increase in the CXCR3 + CCR4- type $1 \mathrm{~T}$ cell population (Figure 5a) and a decrease in the CXCR3- 


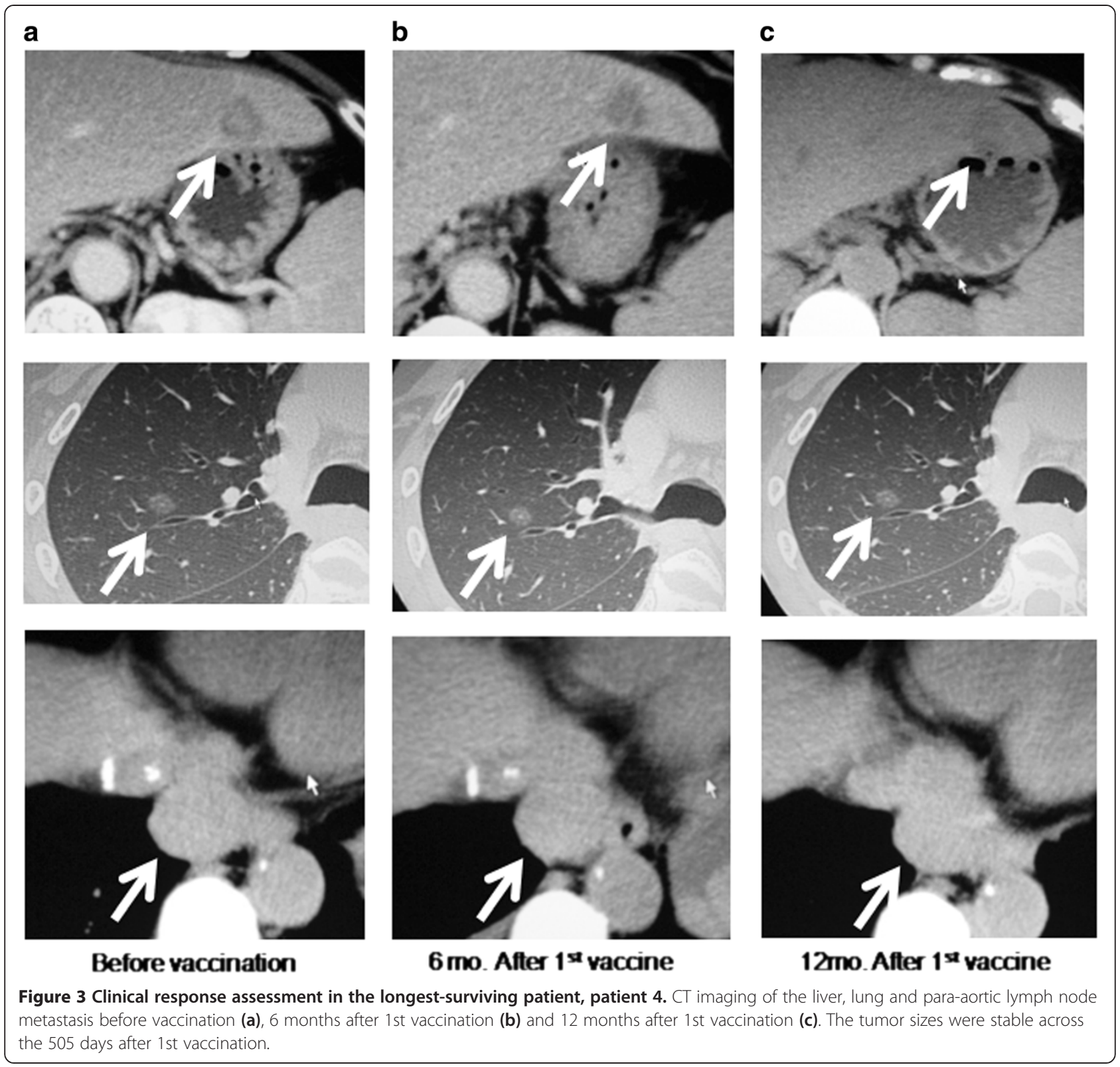

CCR4+ type $2 \mathrm{~T}$ cell population after the $4^{\text {th }}$ vaccination (Figure $5 \mathrm{~b}$ ). In contrast, all the patients with progressive disease (PD) showed a decrease in the CXCR3 + CCR4- T cell population and an increase in the CXCR3-CCR4+ T cell population after the $4^{\text {th }}$ vaccination. Therefore, the type 1 host immune condition was suspected to be an important factor for achieving disease stability through the induction of peptide-specific CTLs in vivo.

\section{Discussion}

It is difficult to detect BTCs in the early stage, and this difficulty is partly responsible for the poor prognosis of the disease. Operation is the most effective treatment, but recurrence or metastasis occurs at a high rate following curative operation. Other than operation, chemotherapy is the only therapy currently available. Nevertheless, GEM plus CDDP, which is the best choice of chemotherapy for BTC, only yields a median overall survival of 11.7 months and progression-free survival of 8.0 months. However, a median overall survival of 9.7 months was realized using a three-peptide vaccination after the failure of standard chemotherapies, and thus this modality might have potential for improving the OS in patients with BTC.

In this study, we selected three new peptides for BTC. CDCA1 is a molecular linker between the kinetochore attachment site and the tubulin subunits. $\mathrm{CDH} 3$ is a 


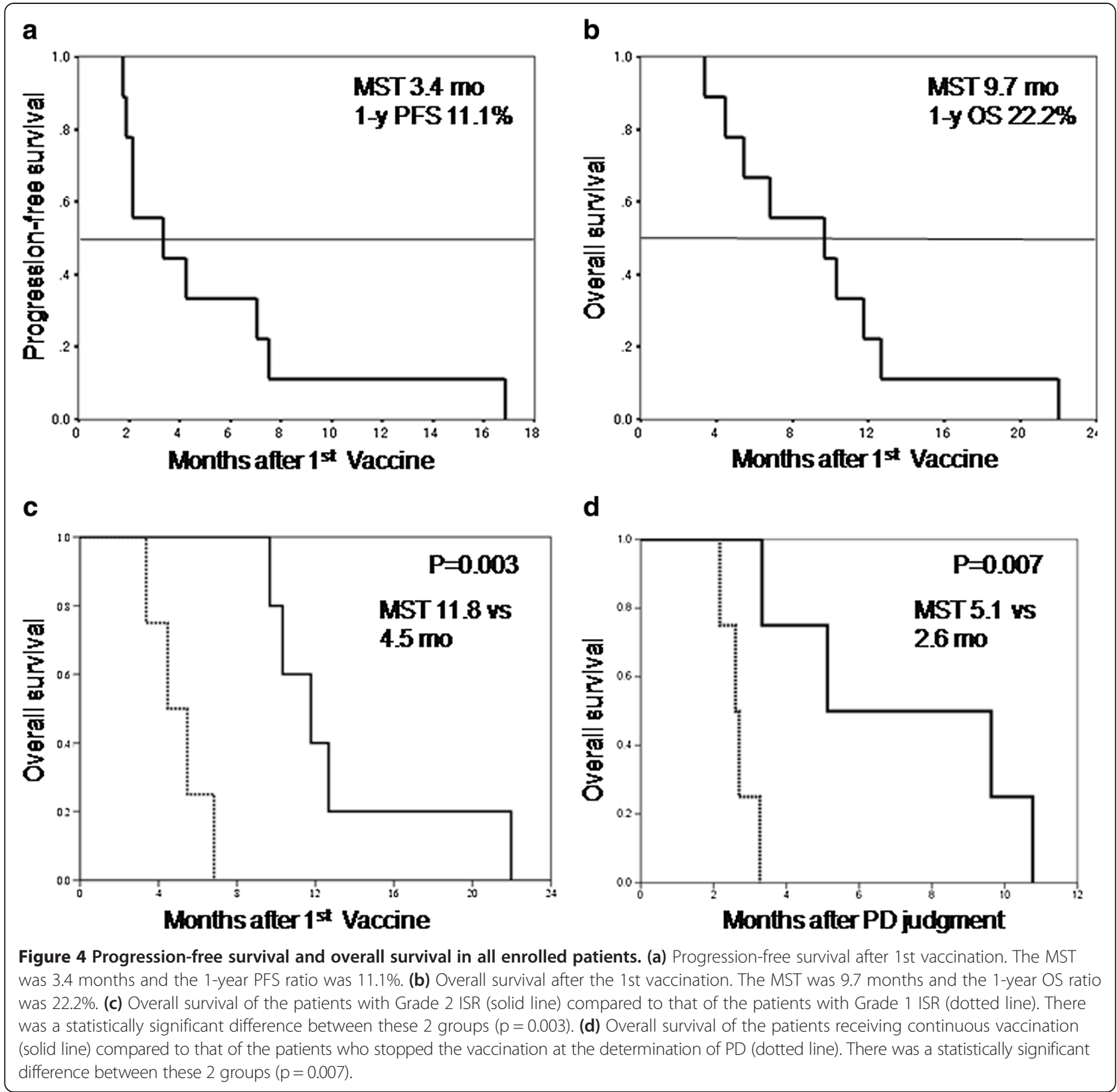

cell-cell adhesion molecule and takes part in the signal transduction for cell growth and differentiation. KIF20A is a conserved motor domain that binds to microtubules. We previously reported on other combinations of peptides for vaccination in patients with BTC. We found that DEPDC1 and LY6K strongly induced antigen-specific CTLs after the 4th vaccination. In contrast, IMP3 and TTK induced CTLs only weakly and late after the vaccination. The three-peptide vaccination in this study also showed a delayed induction of peptide-specific CTLs. We speculate that this might have been due to differences in the abilities of the peptides to induce a host immune response. In these cases, most of the patients were judged as having PD before the strong CTLs were induced in vivo. The protocol of this study permitted the continuation of vaccination after the diagnosis of $\mathrm{PD}$, and the patients who continued vaccination after the start of PD had a strong CTL induction and showed better prognosis compared with other patients who stopped the vaccination at the time of PD judgment. Therapeutic cancer vaccination seems to show a delayed clinical effect [17] and the early discontinuance of vaccination might cause a misappraisal of the true capacity of the cancer vaccine. Therefore, there may be need of a further clinical study in which 

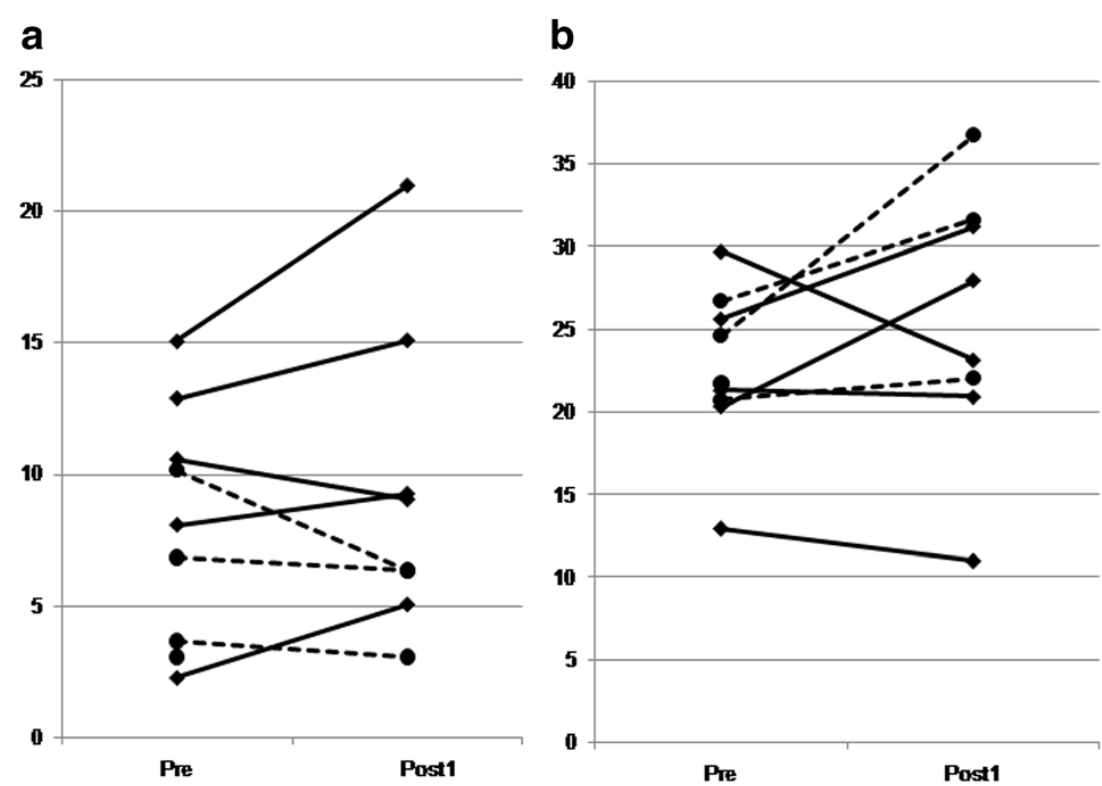

Figure 5 Kinetics of type $1 \mathrm{~T}$ cell population and type $\mathbf{2} \mathrm{T}$ cell population after vaccination. (a) The population of CXCR3 + CCR4- type $1 \mathrm{~T}$ cells increased in most of the patients with stable disease (SD) (solid line) and decreased all the patients with progressive disease (PD) (dashed line) after 4 vaccinations. (b) The population of CXCR3-CCR4+ type $2 \mathrm{~T}$ cells was decreased in most of the patients with SD (solid line) and increased in all the patients with PD (dashed line) after 4 vaccinations.

the vaccination is continued for the long term even after a diagnosis of PD in the early stage of study, because the induction of CTLs was often fairly slow.

Several phase III randomized studies of cancer vaccines have been performed [18], but very few of them were successful [19]. The clinical efficacy of cancer vaccines is currently limited because of the immune checkpoint. Anti-CTLA-4 mAb (ipilimimab) [20], anti-PD-1 $[21,22]$ and PD-L1 [23] have shown promising results in some clinical studies. Although the blockage of the immune checkpoint itself is an effective therapy, it also seems to be necessary to administer the cancer antigen-specific CTLs. Cancer peptide vaccines could induce antigen-specific CTLs in vivo, so the combination of a cancer vaccine and immune checkpoint blockade would be a more successful anti-cancer strategy in the future. Another approach might be to improve the immune condition of the host. A proper number of lymphocytes, especially type $1 \mathrm{~T}$ cells, seems to be needed to acquire a good immune response, which in turn has been associated with a better prognosis $[24,25]$. In order to ensure the success of clinical trials, a new classification method or biomarker is needed to stratify patients according to their immune condition [26-30].

In this report, a new three-peptide vaccine was shown to be safe and to elicit an effective immune response in patients with advanced biliary tract cancer. No patients exhibited a CR or PR, but it was suggested that the OS could be extended by continuous administration of this vaccination. In order to establish this immunotherapy as the standard therapy for biliary tract cancer, it will be necessary to assess the survival improvement in a phase II/III randomized trial with an appropriate number of subjects. We have reported 4 peptides previously and 3 new peptides in this study. All 7 of these peptides could be used simultaneously for patients with advanced BTC, or one or more of them could be selected for patients in an adjuvant setting after operation and examination of the antigen expression profile in their tumor cells.

\section{Conclusions}

We have shown that a cancer peptide vaccine therapy using a mixture of three peptides was well tolerated and could induce peptide-specific CTLs in patients with advanced BTC. The peptide vaccine was found to have a sufficient effect on survival to merit further evaluation in clinical trials.

\section{Additional file}

Additional file 1: Algorithm of the assessment of CTL response to antigen.

\section{Abbreviations}

BTC: Biliary tract cancer; CBDCA: Carboplatin; CDCA1: Cell division cycle associated 1; CDDP: Cisplatin; CDH3: Cadherin 3; CTCAE: Common terminology criteria for adverse events; CTL: Cytotoxic T lymphocyte; DTX: docetaxcel; ELISPOT: Enzyme-linked immunospot; GEM: Gemcitabine; HPLC: High-performance liquid chromatography; IFA: Incomplete Freund's adjuvant; KIF20A: Kinesin family member 20A; OS: Overall survival; PBL: Peripheral blood lymphocyte; PFS: Progression-free survival; SD: Stable disease; TS-1: Tegafur-gimeracil-oteracil potassium. 


\section{Competing interests}

The authors declare that they have no competing interests.

\section{Authors' contributions}

AA participated as the principle investigator of the study and drafted the manuscript. NT and NM participated the acquisition of data. KT coordinated the analysis of immunological data. YK and RO participated in the design and coordination of the study. TO and MY participated in the study supervision. All authors read and approved the final manuscript.

\section{Acknowledgements}

The authors would like to thank Prof. Yusuke Nakamura, Dr. Takuya Tsunoda, and Dr. Koji Yoshida of the Laboratory of Molecular Medicine, Human Genome Center, Institute of Medical Science, The University of Tokyo, for their excellent advice and cooperation and for providing all the peptides.

\section{Author details}

${ }^{1}$ Department of Gastroenterological Surgery, Tokyo Women's Medical University, 8-1 Kawada-cho, Shinjuku-ku, Tokyo 162-8666, Japan. ${ }^{2}$ Institute of Advanced Biomedical Engineering and Science, Tokyo Women's Medical University, 8-1 Kawada-cho, Shinjuku-ku, Tokyo 162-8666, Japan. ${ }^{3}$ Department of Immunology, Juntendo School of Medicine, 2-1-1 Hongo, Bunkyo-ku, Tokyo 113-8421, Japan.

\section{Received: 26 September 2013 Accepted: 4 March 2014} Published: 7 March 2014

\section{References}

1. Okusaka T, Nakachi K, Fukutomi A, Mizuno N, Ohkawa S, Funakoshi A, Nagino M, Kondo S, Nagaoka S, Funai J, Koshiji M, Nambu Y, Furuse J, Miyazaki M, Nimura Y: Gemcitabine alone or in combination with cisplatin in patients with biliary tract cancer: a comparative multicenter study in Japan. British J Cancer 2010, 103:469-474.

2. Valle J, Wasan H, Palmer DH, Cunningham D, Anthoney A, Maraveyas A, Madhusudan S, Iveson T, Hughes S, Pereira SP, Roughton M, Bridgewater J: Cisplatin plus Gemcitabine versus Gemcitabine for Biliary Tract Cancer. N Engl J Med 2010, 362:1273-1281.

3. Schwartzentruber DJ, Lawson DH, Richards JM, Conry RM, Miller DM, Treisman J, Gailani F, Riley L, Conlon K, Pockaj B, Kendra KL, White RL, Gonzalez R, Kuzel TM, Curti B, Leming PD, Whitman ED, Balkissoon J, Reintgen DS, Kaufman H, Marincola FM, Merino MJ, Rosenberg SA, Choyke P, Vena D, Hwu P: gp100 Peptide Vaccine and Interleukin-2 in Patients with Advanced Melanoma. N Engl J Med 2011, 364(22):2119-21127.

4. Kono $K$, linuma $H$, Akutsu $Y$, Tanaka H, Hayashi N, Uchikado $Y$, Noguchi T, Fujii H, Okinaka K, Fukushima R, Matsubara H, Ohira M, Baba H, Natsugoe S, Kitano S, Takeda K, Yoshida K, Tsunoda T, Nakamura Y: Multicenter, phase II clinical trial of cancer vaccination for advanced esophageal cancer with three peptides derived from novel cancer-testis antigens. J Translational Med 2012, 10:141.

5. Suzuki H, Fukuhara M, Yamaura T, Mutoh S, Okabe N, Yaginuma $H$, Hasegawa T, Yonechi A, Osugi J, Hoshino M, Kimura T, Higuchi M, Shio Y, Ise K, Takeda K, Gotoh M: Multiple therapeutic peptide vaccines consisting of combined novel cancer testis antigens and anti-angiogenic peptides for patients with non-small cell lung cancer. J Translational Med 2013, 11:97.

6. Obara W, Ohsawa R, Kanehira M, Takata R, Tsunoda T, Yoshida K, Takeda K, Katagiri T, Nakamura Y, Fujioka T: Cancer peptide vaccine therapy developed from oncoantigens identified through genome-wide expression profile analysis for bladder cancer. Jpn J ClinOncol 2012, 42(7):591-600.

7. Matsushita N, Aruga A, Inoue Y, Kotera Y, Takeda K, Yamamoto M: Phase I clinical trial of a peptide vaccine combined with tegafur-uracil plus leucovorin for treatment of advanced or recurrent colorectal cancer. Oncol Rep 2013, 29:951-959.

8. Noguchi M, Kakuma T, Uemura H, Nasu Y, Kumon H, Hirao Y, Moriya F, Suekane S, Matsuoka K, Komatsu N, Shichijo S, Yamada A, Itoh K: A randomized phase II trial of personalized peptide vaccine plus low dose estramustine phosphate (EMP) versus standard dose EMP in patients with castration resistant prostate cancer. Cancer Immunol Immunother 2010, 59:1001-1009.

9. Noguchi M, Moriya F, Suekane S, Ohnishi R, Matsueda S, Sasada T, Yamada A, Itoh $\mathrm{K}$ : A phase II trial of personalized peptide vaccination in castration- resistant prostate cancer patients: prolongation of prostate-specific antigen doubling time. BMC Cancer 2013, 13:613.

10. Okuyama R, Aruga A, Hatori T, Takeda K, Yamamoto M: Immunological responses to a multi-peptide vaccine targeting cancer-testis antigens and VEGFRs in advanced pancreatic cancer patients. Oncolmmunology 2013, 2:11. e27010.

11. Asahara S, Takeda K, Yamao K, Maguchi H, Yamaue H: Phase I/II clinical trial using HLA-A24-restricted peptide vaccine derived from KIF20A for patients with advanced pancreatic cancer. J Translational Med 2013, 11:291.

12. Sawada Y, Yoshikawa T, Nobuoka D, Shirakawa H, Kuronuma T, Motomura Y, Mizuno S, Ishii H, Nakachi K, Konishi M, Nakagohri T, Takahashi S, Gotohda N, Takayama T, Yamao K, Uesaka K, Furuse J, Kinoshita T, Natatsura T: Phase I Trial of a Glypican-3-Derived Peptide Vaccine for Advanced Hepatocellular Carcinoma: Immunologic Evidence and Potential for Improving Overall Survival. Clin Cancer Res 2012, 18(13):3686-3696.

13. Aruga A, Takeshita N, Kotera Y, Okuyama R, Matsushita N, Ohta T, Takeda K, Yamamoto M: Long-term vaccination with multiple peptides derived from cancer-testis antigens can maintain a specific T-cell response and achieve disease stability in advanced biliary tract cancer. Clin Cancer Res 2013, 19(8):2224-2231.

14. Harao M, Hirata S, Irie A, Senju S, Nakatsura T, Komori H, Ikuta Y, Yokomine K, Imai K, Inoue M, Harada K, Mori T, Tsunoda T, Nakatsuru S, Daigo Y, Nomori H, Nakamura Y, Baba H, Nishimura Y: HLA-A2-restricted CTL epitopes of a novel lung cancer-associated cancer testis antigen, cell division cycle associated 1, can induce tumor-reactive CTL. Int J Cancer 2008, 123:2616-2625.

15. Imai K, Hirata S, Irie A, Senju S, Ikuta Y, Yokomine K, Harao M, Inoue M, Tsunoda T, Nkatsuru S, Nakagawa H, Nakamura Y, Baba H, Nishimura Y: Identification of a novel tumor-associated antigen, cadherin 3/P-cadherin, as a possible target for immunotherapy of pancreatic, gastric, and colo-rectal cancers. Clin Cancer Res 2008, 14(20):6487-6495.

16. Taniuchi K, Nakagawa H, Nakamura T, Eguchi H, Ohigashi H, Ishikawa O, Katagiri T, Nakamura Y: Down-regulation of RAB6KIFL/KIF20A, a kinesin involved with membrane trafficking of discs large homologue 5, can attenuate growth of pancreatic cancer cell. Cancer Res 2005, 65(1):105-112.

17. Chen $\Pi$ : Statistical issues and challenges in immuno-oncology. J Immuno Ther Cancer 2013, 1:18.

18. Ellis P, Gladkov O, Pereira JR, Eberhardt WEE, Helwig C, Schroder A, Shepherd FA, Ramlau R, Wickart-Johansson G, Trigo JM, Spira A, Tremblay L, Nyman J, Butts C, Socinski MA, Mitchell PL, Thatcher N, Havel L, Krzakowski M, Nawrocki S, Ciuleanu TE, Bosquee L: Tecemotide (L-BLP25) versus placebo after chemoradiotherapy for stage III non-small-cell lung cancer (START): a randomized, double-blind, phase 3 trial. Lancet Oncol 2014, 15:59-68.

19. Cheever MA, Higano CS: PROVENGE (Sipuleucel-T) in Prostate Cancer: The First FDA-Approved Therapeutic Cancer Vaccine. Clin Cancer Res 2011, 17(11):3520-3526

20. Robert C, Thomas L, Bondarenko I, O'Day S, Weber J, Garbe C, Lebbe C, Baurain JF, Testori A, Grob JJ, Davidson N, Richards J, Maio M, Hauschild A, Miller WHJ, Gascon P, Lotem M, Harmankaya K, Ibrahim R, Francis S, Chen TT, Humphrey R, Hoos A, Wolchok JD: Ipilimumab plus Dacarbazine for Previously Untreated Metastatic Melanoma. N Engl J Med 2011, 3646(26):2517-2526.

21. Topalian SL, Hodi FS, Brahmer JR, Gettinger SN, Smith DC, McDermott DF, Powderly JD, Carvajal RD, Sosman JA, Atkins MB, Leming PD, Spigel DR, Antonia SJ, Horn L, Drake CG, Pardoll DM, Chen L, Sharfman WH, Anders RA, Taube JM, McMiller TL, Xu H, Korman AJ, Jure-Kunkel M, Agrawal S, McDonald D, Kolia GD, Gupta A, Wigginton JM, Sznol M: Safety, Activity, and Immune Correlates of Anti-PD-1 Antibody in Cancer. N Engl J Med 2012, 366(26):2443-2454

22. Hamid O, Robert C, Daud A, Hodi FS, Hwu WJ, Kefford R, Wolchok JD, Hersey P, Joseph RW, Weber JS, Dronca R, Gangadhar TC, Patnaik A, Zarour H, Joshua AM, Gergich K, Elassaiss-Schaap J, Algazi A, Mateus C, Boasberg P, Tumeh PC, Chmielowski B, Ebbinghaus SW, Li XN, Kang SP, Ribas A: Safety and Tumor Responses with Lambrolizumab (Anti-PD-1) in Melanoma. N Engl J Med 2013, 369(2):134-144.

23. Brahmer JR, Tykodi SS, Chow LQM, Hwu W-J, Topalian SL, Hwu P, Drake CG, Camacho LH, Kauh J, Odunsi K, Pitoto HC, Hamid O, Bhatia S, Martins R, Eaton K, Chen S, Salay TM, Alaparthy S, Grosso JF, Korman AJ, Parker SM, Agrawal S, Goldberg SM, Pardoll DM, Gupta A, Wigginton JM: Safety and Activity of Anti-PD-L1 Antibody in Patients with Advanced Cancer. N Engl J Med 2012, 366(26):2455-2465. 
24. Yoon SH, Yun SO, Park JY, Kim EK, Sohn HJ, Cho HI, Kim TG: Selective addition of CXCR3(+) CCR4(-) CD4(+) Th1 cells enhances generation of cytotoxic T cells by dendritic cells in vitro. Exp Mol Med 2009, 41(3):161-170.

25. Elliott RL, Head JF: Adjuvant breast cancer vaccine improves disease specific survival of breast cancer patients with depressed lymphocyte immunity. Surg Oncol 2013, 22:172-177.

26. Galon J, Pages F, Marincola FM, Thurin M, Trinchieri G, Fox BA, Gajewski TF, Ascierto PA: The immune score as a new possible approach for the classification of cancer. J Transl Med 2012, 10:1.

27. Ogi C, Aruga A: Clinical evaluation of therapeutic cancer vaccines. Hum Vaccines Immunother 2013, 9(5):1049-1057.

28. Ogi C, Aruga A: Immunological monitoring of anticancer vaccines in clinical trials. Oncolmmunology 2013, 2:8. e26012.

29. Aarntzen EHJG, Bol K, Schreibelt G, Jacobs JFM, Westerhuis WJ, Van Rossum MW, Adema GJ, Figdor CG, Punt CJA, De Vries JM: Skin-Test infiltrating lymphocytes early predict clinical outcome of dendritic cell-based vaccination in metastatic melanoma. Cancer Res 2012, 72(23):6102-6110

30. Wolchok JD, Hoos A, O'Day S, Weber JS, Hamid O, Lebbe C, Maio M, Binder M, Bohnsack O, Nichol G, Humphrey R, Hodi FS: Guidelines for the evaluation of immune therapy activity in solid tumors: immune-related response criteria. Clin Cancer Res 2009, 15:7412-7420.

doi:10.1186/1479-5876-12-61

Cite this article as: Aruga et al:: Phase I clinical trial of multiple-peptide vaccination for patients with advanced biliary tract cancer. Journal of Translational Medicine 2014 12:61.

\section{Submit your next manuscript to BioMed Central and take full advantage of:}

- Convenient online submission

- Thorough peer review

- No space constraints or color figure charges

- Immediate publication on acceptance

- Inclusion in PubMed, CAS, Scopus and Google Scholar

- Research which is freely available for redistribution 